\title{
A Comparative Study of Sports Achievement Motivation between Volleyball and Basketball Players of Sunbeam Academy Varanasi
}

\author{
Nishant Singh \\ Research Scholar, Sri Satya Sai University of Technology and Medical Science, Sehore.
}

\begin{abstract}
The purpose of the study was to compare the Sports Achievement Motivation between volleyball and basketball players of Sunbeam Academy, Varanasi and also to find out the status of players in relation to sports achievement motivation. For purpose of the study forty six (twenty three volleyball and twenty three basketball) players were selected from sunbeam Academy Varanasi was taken as a subjects. Sports Achievement Motivation was measured by inventory constructed by M.L Kamlesh. Data was collected by administering questionnaire. All the necessary instructions were given to students and were convinced to answer the entire questions honestly. To find out the difference independent t-test was used at 0.05 level of significance. Findings of the study revealed that there is no significant difference between volleyball and basketball players in relation to sports achievement motivation as calculated $t$ (1.57) was less than tabulated t value (2.01) at 0.05 level of significance. Nature of the game, Age, similar environmental factor and less number of subjects might have brought no significant difference between volleyball and basketball players in relation to sports achievement motivation.
\end{abstract}

Keyword: Sports Achievement Motivation

\section{Introduction}

Sport is an important ingredient of physical education and is a worldwide phenomenon today. The unprecedented popularity and better organization of sports activities and competitions would have been impossible without the recognition of the important of sports competitions in the world. The world has realized the importance of sports for the modern civilizations. (Uppal, 1992)

Sport Psychology is the scientific study of people and their behaviours in sport. The role of a sport psychologist is to recognize how participation in sport exercise and physical activity enhances a person's development.

Achievement motivation comes into picture when an individual knows that his performance will be evaluated that the consequence of his actions will be either a success or a failure and that good performance will produce a feeling of pride in accomplishment. Hence, achievement motive may be considered as a disposition to approach success or a capacity for taking pride in accomplishment when success at one or another activity is achieved (Harold, \& Rosemary, 1979).

\section{Procedure}

In this study, the selection of subjects, selection of variable, administration of questionnaire, collection of data and statistical techniques for the analysis of data has been described.

\section{Selection Of Subjects}

For the present study 23 Male Volleyball players and 23 Male Basketball players are taken of Sunbeam School Varanasi were randomly selected, with age ranged from 14 to 18 years.

\section{Selection Of Variables} variable.

Keeping in mind about specific purpose of the study, the Achievement Motivation were selected as a

\section{Criterion Measures}

For measuring the sports Achievement Motivation of the subjects a questionnaire constructed by Dr. M.L Kamlesh was used. It is a popular tool being used by the psychologists for measuring the sports Achievement Motivation of players

\section{Administration Of Questionnaire}

Respondents were called to a common place when they were not busy and have enough time to spare for testing. Necessary instructions were passed on to the subjects before the administration of each test. No time 
limit for filling in the questionnaire was set, but the subjects were made to respond as quickly as possible once the instructions were clearly understood by them.

\section{Collection Of Data}

Data was collected on School players. Coaches requested to their players to serve as subject for the study. Necessary instructions given to the subjects before administration of the questionnaire in relation to Achievement Motivation of Volleyball and Basketball players.

\section{Statistical Procedure}

The data thus collected were given to statistical treatment computing t-ratio to find out the difference if any between the Volleyball and Basketball players in relation to sports achievement motivation. The obtained results have been presented in the following table. The level of significance was set at $5 \%$.

Table -1 Indicating the Mean Difference of Sports Achievement Motivation between Volleyball and Basketball

\begin{tabular}{|l|l|l|l|}
\hline Team & Mean & S.D & t-value \\
\hline Volleyball & 23.56 & 2.35 & 1.57 \\
\hline Basketball & 25.65 & 5.88 & \\
\hline
\end{tabular}

'Significant at 0.05 , table value $=2.01(\mathrm{df}=44)$.

Table 1 showed that comparisons on the variable of 'Achievement Motivation' between Volleyball and Basketball players. The mean ( \pm standard deviation) values of Volleyball and Basketball players were found to be $23.56( \pm 2.35)$ and $25.65( \pm 5.88)$ respectively. ' $t$ ' value 1.57 was found to be insignificant. at 0.05 level of significance with degree of freedom of 44 and while comparing the two mean values it shows that Basketball players have performed better on the variable 'Achievement Motivation' than their counterpart Volleyball players.

Fig: 1 Mean and SD of Achievement Motivation of Volleyball and Basketball players

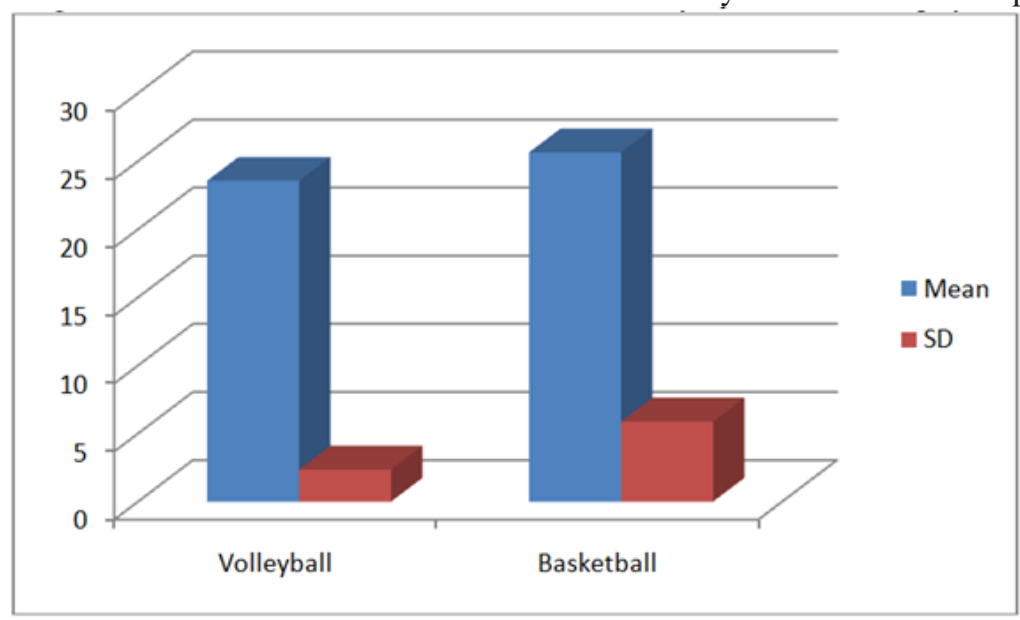

\section{Conclusions}

Findings of the study revealed that there is no significant difference between volleyball and basketball players in relation to sports achievement motivation as calculated $t$ (1.57) was less than tabulated t value (2.01) at 0.05 level of significance. Nature of the game, Age, similar environmental factor and less number of subjects might have brought no significant difference between volleyball and basketball players in relation to sports achievement motivation.

\section{References}

[1]. Johnson U, Ivarsson A. Urban Johnson (2010) "Psychological predictors of sport injuries among junior soccer players" Scandinavian Journal of Medicine Science in Sports.

[2]. Best J.W. (1981) Research in Education:( 4th Ed; Englewood cliffs; Prentice Hall Inc. ) 45,62

[3]. Kamlesh, M.L. (1990). Manual of sports achievement motivation test. NIS Scientific journal, 13 (3),28-39.

[4]. Khan, Z, Haider, Z, Ahmeed, N,\& Khan,S.(2011). Sports achievement motivation and sports competition anxiety: A relationship study. Journal of Education and Practice, 2(4), 